\title{
Representation of Traumas of Displacement in Marie Therese Toyi's Weep Not, Refugee
}

\author{
Astelia Mihayo \\ mihayoastelia@gmail.com \\ Literary and Cultural Studies Program, Universitas Airlangga-Indonesia \\ Stanley Elias \\ stanleyelias86@yahoo.com \\ Department of Literature, University of Dar es Salaam-Tanzania
}

\begin{abstract}
With the ever-increasing outbreak of intrastate and interstate wars since the mid-20th century, Africa has experienced mass displacement of people which has subsequently resulted in an increase of displaced communities in the world. From these displaced communities, African refugees constitute a significant share of the total displaced people in the globe, which count to 68.5 million people. The present study explored representation of traumas of displacement in Marie Therese Toyi's Weep Not, Refugee. The study deployed Ruth Caruth's tenets of trauma studies in literature. The findings of the study affirm the authors use Weep Not Refugee to explore the significant contribution of displacement to delineate and circumscribe Burundian refugees with traumatised and reduced identities in areas of displacement. In most cases, the journey of leaving home and later their lives in refuge of Burundians are explicated to be surrounded by tragic experience and reduced identities that ascribe them to burden and non-entity beings. Moreover, the authors provide an opportunity for readers to explore displacement and its significant contribution to the constructions of cultural trauma among refugees. Because of ethnic war which has led to displacement of Burundians to other areas, Burundians have to lose some cultural aspects and invent new ones for the sake of cultural adjustment in the foreign land they are hosted.
\end{abstract}

Keywords: displacement, reduced identities, trauma

\section{Introduction}

With the ever-increasing outbreak of intrastate and interstate wars since the mid$20^{\text {th }}$ century, Africa has experienced mass displacement of people which has subsequently resulted to increasing of displaced communities in the world. Of these displaced communities, African refugees constitute approximately six million of the total displaced people in the globe which count to 68.5 million people. According to Brooking (2015), displacement prompts to tension and negotiation arising from shifting zones which eventually causes trauma to individuals. In similar view, Mehni, Omar, and Bahar (2015, p. 95) argue that displacement can be approached psychologically to identify the overwhelming "the psychic defences and normal processes of registering memory traces". Of course the foregoing view foregrounds Caruth's (1995) view that literature is like psychoanalysis hence can be approached to understand memories registered in ones' psyche. It is in this light this study sets out to examine the representation 
of traumas of displacement of Burundian refugees in Marie Therese Toyi's Weep Not, Refugee.

This study examines the significant contribution of displacement to delineate and circumscribe Burundian refugees with traumatic and reduced identities refuge. In most cases the journey of leaving home and later their lives in refuge is always surrounded by tragic experience and reduced identities that ascribe them to burden and non-entity beings. Thus, the reading of displacement in the novel focuses on the tragic and brutal memories as Burundians abandons their natal home to escape persecution. We contextualise our study to Caruth's (1995, p. 153) view that "for the survivor of trauma, then the truth of the event may reside not only in its brutal facts, but also in the way that their occurrence defies simple comprehension" to analyse traumatic experiences ascribed to Burundian refugees as they forcibly evacuate the natal home to refuge. Caruth $(1995$, p. 91) recognises trauma as "the response to an expected and overwhelming violent event that is not fully registered neither grasped as they occur but return later in repeated flashbacks, nightmares and other repetitive phenomena". Similar observation is made by Nikro (2014) who supposes trauma to embody existential experiences of atrocity and survival, of coping in the aftermath of personal and social disintegration. Caruth (1996) proposes further that trauma has moving and sorrowful voice. It also cries and is released through the wound. Moreover, as cited in Marder (2006, p. 2), she argues that trauma needs us to imagine that traumatic events do not simply occur in time rather they fracture the very experience of time for the person to whom they "happen".

Set partly in Wirodi and later in Burundi, Weep Not, Refugee is narrated in multiple person point of views and different narrative styles. The story is opened by presenting terrifying war memories told in third person point of view (omnisciently) in the refugee camp of Mabanu in Wirodi. It is the story of Kigeme told in flashbacks that moves from different settings to unfold different life experiences she went through. Kigeme's narrative evolves in terms of memory and trauma of her past while in Burundi. The narrative is later told in first person from whom Kigeme becomes the narrator of her own past. Kigeme describes her memories especially as a secondary school girl who had to flee to Wirodi for her safety, as a result of war in Burundi. Unfortunately, on her way to Wirodi (exile), she witnesses her mother being raped in the open area and drowned into a river. Moreover, she also witnesses her father being chopped into pieces by the soldier, Kiroro, who again rapes her and becomes the father of her only son, Wache Wacheke Watachoka. As of the narrative, Kigeme regards her telling is of herself and of her fellow Burundian refugees whose rights are compromised as a result of war. The narrative shifts as Kigeme and Wache tell their experiences in Mabanu camp in Wirodi. In many cases, the life of the refugees in the camp is surrounded with series of disappointments. of many of their rights, food became scarce and hunger became the life experience in the camp. Hereafter, the story of Wache as a student in Wirodi follows. Wache explains the educational challenges among the refugees, which ranging from financial support to language problems. Besides, he also tells the way the system unfairly places them in the marginalised position and the way it erodes their dignity. In addition, the story of Wache returning to Burundi in search of his father is unfolded. Wache is victimized at near death and decides to go back to Wirodi and later as a school dropout who after series of sufferings he is by luck elevates to a business man in Wirodi and later in Burundi.

\section{Methodology}

The study deploys textual analysis method in interpreting displacement as traumatic experience in Weep Not, Refugee. Textual analysis is primarily used to critically analyse traumas associated with displacement ascribed to individuals after leaving their natal homes through the use of words, clauses, symbols, metaphors and general language of the novel. Therefore, as for critical analysis of traumas of displacement in the text under study, it uses three different but related methods namely, close reading, contextual method, and thematic methods. First, this study places Weep Not, Refugee under close reading method. The assumption under this 
method of the text under this study is selfenclosed and self-sustaining enterprise (Swingewood and Alan, 1972). Thus, in order to approach Weep Not, Refugee to find out the ways in which traumas of displacement are represented, we pay close attention to the text itself with no consideration to external factors. The authors also consider Rivkin's (2004, p. 6) argument that close reading explicate the ways in which "literature embodies or concretely enacts universal truth" through language that is interpreted denotatively and connotatively. Therefore, through close reading, Toyi's Weep Not, Refugee is read to interpret the meanings of words, phrases, clauses, and sentences in the text and their inferences in terms of symbolic and metaphoric configuration. Secondly, Toyi's Weep Not, Refugee is placed in the contexts that influenced its production. In a point of fact, Weep Not, Refugee is shaped by intrastate and interstate wars of the Great Lakes region. Therefore, the selected text is read with reference to the socio-cultural factors surrounding the production of the text. In a point of fact, here we find the meaningful interaction between internal structures of the text (language of the text) and the context of its production. According to Swingewood and Alan (1972), literature cannot distance itself from the society and context that created it. Thus, Weep Not, Refugee cannot distance itself from the state of violence that characterises Great Lakes region. As argued by Swingewood and Alan (ibid), the task of the researcher is to translate the internal structures of the text and the context (society) into public meaning. Therefore, the contextual method applied is in line with the close reading. It is in order to associate the text to the insights to scrutinize the portrayal of traumas of displacement. Thirdly, the thematic analysis method places other two methods in thematic identification of trauma of displacement. Guided by the topic under this study, the authors consider on how characterisation in the novel informs war traumas of Burundian people across the Great Lakes region.

\section{Analysis and Discussion}

In the foremost, Marie Therese Toyi reinvents the conception of refugee-as it is the title of her novel, Weep Not, Refugee-to literary explicates associated traumas of displacement. Meanwhile, the agreed standard definition by the United Nations High Commissions for Refugees (UNHCR) identifies someone as a refugee when he or she is forced to flee his or her country because of persecution, war, or violence. According to Toyi, a refugee is someone who is "forced to leave a mother-country and who has no right at all, if not the right to be told, what to do, how to do it, how to live, and how to die" (Toyi, 2014, p. 155). This is metaphorically signifying the much reduced identities that refugees are ascribed after leaving their natal home. As of the narrative, the authors portray refugee as a signal burden of torture who suffers yet ready to bear all the problems. Refugees exist in the margin of the common citizens of the host country and so they should "not weep".

Equally to Fanon (1967), he identifies "otherness" as the refugees in the narrative that they possess traumatised identities of the colonized self. Of a particular importance to the argument are the embedded traumas that the refugees bear. It is that they are deprived their rights to live, the information, and many others as alluded in the following instance; "Abuses were heaped on us, and we had to swallow them silently, preferably with a smile on the lips, or were to be taken back to the face of machetes, bullets, and this time trial" (Toyi, 2014, pp. 15-16).

In most cases, the leaving of home and entering new home ascribed Burundian bodies to reduced status that rendered them no defence and had enough humanitarian assistance in the refugee camp as explicated in the following, "we were defenceless because nobody was your relative there; slaves of this new country that was the souvenir, which my mother wanted to keep by calling me Mujawaha" (Toyi, 2014, p. 16).

Also the move from Burundi to Wirodi and being integrated to Wirodi community forced Burundian refugees to learn new ways of life including language. The learning of new language and loss of French, which they were used to resulted to linguistic dilemma. This linguistic dilemma has eventually culminated to marginalization and mistreatments of 
Burundian people in Wirodi. Of course, displacement is portrayed to significantly contribute to the constructions of cultural trauma among refugees. In the novel, Wache narrates on how displacement has led them to linguistic dilemma the moment they become enrolled to school as in the instance below:

We were luck to understand this simple French sentence. The rest of what he said was what we came to call fonofono in our school jargon. It was a combination of sounds, with no message to us since we could not understand it.....I was born when the use of French had not yet disappeared from the mouth of some refugees, who though that they could still use the language to get a job. Later when they saw nothing was coming the turned more to Kiswahili (Toyi, 2014, pp. 132-133).

In the foregoing passage, Wache narrates what it can be argued as linguistic dilemma of the displaced bodies that causes cultural trauma as one tries to remember his or her past. In this case, Wache recalls the memories of the use of French among family members but because of displacements they had to switch to the use of Kiswahili. Of the similar view, Brooking (2015) argues that the displacement rises questions permeating to shifting zones of contacts in linguistics, culture, and many other aspects. As of this reason, there is always a negotiation of what is used and what is really in the field, which in turn lead to the construction of cultural trauma (ibid). Wache's trauma in this particular case evolves from the fact that he has crossed the borders during the time of crisis and the lost ability to comprehend the language due to crisis.

Toyi places displacement at the centre of the plot of the narrative. More importantly, displacement is much associated with calamities that displaced bodies encounter. For example, in the prologue of the novel the author portrays the impacts of the recurring civil wars in Burundi that among others has caused displacement of bodies mercilessly. As a result of forceful migration, Burundian refugees are always in tears and on move for leaving their natal home. According to Caruth (1995), traumatised individuals always display obsession of events or images of once they underwent in their lifetimes. In a point of fact, displacement and all of its journeys from Burundi signify painful experiences that Burundian bodies suffer from. Noting this, the author introduces the readers with the journey of leaving home as a traumatic experience as in the following instance,

Listen and hear the message of trumpets and drums: they announce another war, the nth war. A time for the ground to open and engulf corpses, and or the mountains to bleed again, for the nth time. Great Lakes of tears of countless refugees on the move since times immemorial, repeatedly starting from scratch works shattered by merciless wars (Toyi, 2014, p. 1).

In the foregoing paragraph of the prologue of the novel, displacement as a result of civil and interstate wars in the Great Lakes region has been there since time immemorial. In so, saying it is true that there have been episodes of mass displacement refugees from Burundi to areas nearer local, of course in Wirodi and other countries. This corroborates Ongayo's (2014) findings that since the 1972 around 100.000 people died in Burundi and approximately 200.000 causalities and more than this number have been displaced internally or in places nearer local due to violent conflicts that have culminated to civil wars. Similarly, an observation is made by Takkunen (2017) who argues that Burundi alone is estimated to have lost 1000 people and more than 8000 been exiled for political and security reasons and $300-800$ been abducted. Of a particular importance to these finding is displaced Burundian bodies and their journey of leaving home represented as traumatic experience. In most cases, the journey of refugees to Wirodi as of the narrative informs survival and escapism from violent conflicts and wars in their home country.

Similarly, displacement during the time of chaos and civil wars encompasses burden of killings and sufferings. Throughout Kigeme's narrative, the author highlights the crisis of humanity as a result of displacement. Importantly, while in the refuge in Wirodi, refugees have no equal rights as Wirodi 
citizens. As for Kigeme's narrative, they had no options as their natal home has vomited them out by machetes and bullets and so they had to bear all the sufferings. Alluding this particular case, Toyi deploys trauma to describe characters' journey of escapism from violent conflicts and civil wars in Burundi as in the following instance;

We slept at the gate of the office; there was no safer place for us. The next morning our number increased. Margaret and her son Clement joined us, claiming that they needed special protection. Margaret was a Tutsi and her son Clement feared for the security of this brave woman who had taken a way just for the survival of her son (Toyi, 2014, p. 67).

In the foregoing paragraph, the author portrays that in most cases displacement had been for security reason yet it had encompassed crisis of human right at first place. In the paragraph, Kigeme transports us to her previous past as she strives to circumvent, being deprived of her life and of her son, Wache. In addition to Kigeme's narrative, the author introduces the representation of another narrative through which we can explore the trauma of women during violence and civil wars. Margaret had evacuated to Wirodi to secure her son who belonged to Tutsi, the 'most wanted' group in Burundi. According to Mbonyingingo (2018), the Tutsis minority had dominated the regime and the power in Burundi. Noting the indifference on the war that Toyi narrates, Mbonyingingo (2018) argues that the war was against Tutsi and so they had to flee to Wirodi. Accordingly, the displacement from Burundi to Wirodi appears to be reminiscent of many war survivors' memories including Kigeme.

Again, through Wache and Kigeme the author represents the displacement to inform recurring memories that the characters try to circumvent. The images of being displaced as refugees is registered to refugees' psyche as wounds as in the instance "I grew up with a wound, the wound of being a refugee. This wound bled as often as crises emerged" (Toyi, 2014 , p. 28). Wache narrates the way the displacement has resulted to non-entity beings as Mehni, Omar, Baizura, and Bahar (2017) assert that being displaced and dislocated in many ways renders one with traumatised reduced identities. In the instance "our country had just vomited us out of its bosom, with machetes and bullets, and the hosts had nothing to love in those fugitives, all poor and hungry looking, with no car, no house, nothing" (Toyi, 2014, p. 15). Wache explicates on the way refugeeism has reduced their status to nonentity beings who survive under minimal human help both from Wirodi and international organs responsible for refugees' right. The memories of seeking for asylum remind Wache times of displacement and crisis of humanity every time when crisis emerged. In similar way, in this instance, "herself an orphan refugee, she had seen her mother raped in the open and drowned in Gidi River; her rich father also chopped into pieces and left to the mercy of vultures. By the time she finally succeed to sneak into Wirodi, she was carrying in her frail body a double wound of rape and of unwanted pregnancy" (Toyi, 2014 , p. 5). More importantly, the fact that asylum seeking is traumatising cannot surpass the fact that the whole journey or process of displacement from Burundi had incidents that displaced bodies which had to bear. As of the narrative, Kigeme got pregnancy as she was fleeing to Wirodi. These memories of being raped while rescuing her from civil wars have been registered in her psyche and so keep recurring as flashbacks and thoughts throughout her entire life.

Situated partly in the distant past, the author uses Munuko story to interrogate the traumas and genealogy of displacement pertinent to Burundian bodies. Munuko was a Burundian, a poor boy then, who fled the country in 1940's after he had failed to pay colonial taxes. Central to Munuko's story is trauma of displacement and plight of ruling regime in Burundi.

Munuko had left home in 1940's when a poor man who could not afford to pay thee heavy colonial taxes sought peace in a selfinflicted exile to anyone of the more tolerant neighbouring countries (Toyi, 2014, p. 15).

The leaving of home of Munuko was not by his consents rather it was due to burdens of 
poverty, which was caused by the colonial ruling regime. Here the author provides an opportunity to imagine the genealogy of displacement that seems to have its genesis during colonial times. As of this narrative impositions resulted from the ruling regime set standards for someone to survive or else to seek for self-inflicted exile. On the other hand, Munuko who had stayed in Wirodi-Fasita for some many years became the only hope for Kigeme while in Wirodi. Meeting Munuko meant to unchain herself from troubles of displacement and homelessness. Munuko is symbolic of rare possibility where displaced bodies manage to ascend to prosperous and privileged position. Though, at last Kigeme who spends days in search of Munuko becomes disillusioned later and opt back for refugeeism in Mabanu camp.

Generally, Marie Therese Toyi's presents an opportunity to imagine her experience in Burundi in form of collective war memories and identity crisis of the war survivors in foreign land. Therefore, the reading of Weep Not Refugee corroborates Durrant (2012, p. 100) argument that:

the novelist must turn himself into the ghost or spirit of his own past and offer himself, in the form of his work, as a collective memory) or more accurately, as the memory of a collective)that his readers must learn to survive or "subsist" on in lieu of a disappeared ancestry.

Following what Durrant argues, Marie Therese Toyi represents her past in form of collective memories from the intra-continental diaspora (Nigeria) where she currently lives after fleeing her natal home, Burundi, in 2000s. Marie Therese Toyi abandons her natal home few years after twelve years of ethnic wars between Hutu and Tutsi. Importantly, the angle that the author situates herself as a bearer and witness of the ethnic wars between Hutus and Tutsis as well as diasporic writer, enables her submission of critical representation of the collective trauma of powerless, and displaced bodies in exile in different host countries. According to Tembo (2017), the writers writing at distant angle as diasporic or migrant portray among others subjectivities that would be difficult to write in their homelands. Building on this foregoing argument, the author uses Weep Not, Refugee as narrational voice and to highlight the vices and human right crisis of powerless, homeless, jobless, and stateless individuals during violence and in the time of displacement.

\section{Conclusion}

Marie Therese Toyi uses Weep Not Refugee to explore the significant contribution of displacement to delineate and circumscribe Burundian refugees with traumatised and reduced identities in Wirodi. Through redefinition of refugee's status, the author metaphorically ascribes Burundians with traumatised identities and the life in the margin while living in the areas of displacement. In most cases, the journey of leaving home and later their lives in Wirodi of Burundians is explicated to be surrounded by tragic experience and reduced identities that ascribe them to burden and non-entity beings. Moreover, the author provides an opportunity for readers to explore displacement and its significant contribution to the constructions of cultural trauma among refugees. Because of ethnic war which has led to displacement of Burundians to other areas, Burundians have to lose some cultural aspects and invent new ones for the sake of cultural adjustment in the foreign land they are hosted. Of course, the author portrays negotiations of cultural identities of Burundian refugees in Wirodi and its aftermath of such negotiations that has resulted loss of their homeland cultural values and traditions. What is most important here, the author places displacement at the centre of misfortunes, tragic, and loss experiences that Burundian refugees face the moment they evacuate their natal home. 


\section{References}

Brooking, Trish. (2015). Displacement and Discoveries: Cultural Trauma and Polish Child Refugees in Contemporary Australasian Fiction. Libri \& Liberi, 4(1), 61-84.

Caruth, Cathy. (1995). Trauma: Exploration in Memory. Baltimore: Johns Hopkins University Press.

Durrant, Samuel. (2012). Surviving Time: Trauma, Tragedy, and the Postcolonial Novel, 1(1), 95-117.

https://doi.org/10.1353/jlt.2012.0002

Fanon, Franz. (1967). Black Skin White Mask. London: Pluto Press.

Marder, Eve. (2006). Trauma and Literary Studies: Some "Enabling Questions." Reading On, 1, 1-6. Retrieved from http://is.gd/vzyHuQ

Mbonyingingo, Audace. (2018). War Memories and the Refugees' Representation in Marie-Thérèse Toyi's Weep Not, Refugee War Memories and the Refugees' Representation in, 7408. https://doi.org/10.1080/23277408.201 8.1441007

Mdika, Nick., \& Tembo, H. (2017). Trauma in Selected Eastern African Fiction and Life Writing on Civil Wars, 2000-2014. Stellenbosch.

Mehni, Masoumeh, Omar, Noritah, \& Bahar, Ida Baizura Binti. (2015). Trauma of Displacement in V.S. Naipaul's the Mimic men. Asian Social Science, 11(24), 95104. https://doi.org/10.5539/ass.v11n24p9 5

Mehni, Masoumeh, Omar, Noritah, \& Bahar, Ida Baizura Binti. (2017). Tr s The Mimic Menauma of Displacement in V.S. Naipaul's, 11(24), 95-104. https://doi.org/10.5539/ass.v11n24p9 5

Nikro, N. S. (2014). Situating Postcolonial Trauma Studies. Postcolonial Text, 9(2).
Ongayo, Antony. (2014). Migration in Burundi: History, Current Trends and Future Prospects Migration in Burundi: History, Current Trends, and Future Prospects Paper Series: Migration and Development Country Profiles Maastricht Graduate School of Governance, (September). https://doi.org/10.13140/2.1.3084.736 6

Rifkin, Jeremy. and M. R. (2004). Introduction: Feminist Paradigms. Eds., Rivkin, Julie and Ryan, Michael. Literary Theory: An Anthology. Blackwell Publishers Ltd.

Swingewood, Alan and D. L. (1972). The Sociology of Literature. London: Mac Gibbon and Kee.

Takkunen, J. (2017). Local Conceptualisations of Violence and dialogue in Burundi's Post-electoral crisis.

Toyi, Marie Therese. (2014). Weep Not, Refugee. Benin City-Nigeris: Good-Book Publications. 